\title{
RNA quantification using gold nanoprobes - application to cancer diagnostics
}

\author{
João Conde ${ }^{1}$, Jesús M de la Fuente ${ }^{2}$, Pedro V Baptista ${ }^{1 *}$
}

\begin{abstract}
Molecular nanodiagnostics applied to cancer may provide rapid and sensitive detection of cancer related molecular alterations, which would enable early detection even when those alterations occur only in a small percentage of cells. The use of gold nanoparticles derivatized with thiol modified oligonucleotides (Au-nanoprobes) for the detection of specific nucleic acid targets has been gaining momentum as an alternative to more traditional methodologies. Here, we present an Au-nanoparticles based approach for the molecular recognition and quantification of the $B C R-A B L$ fusion transcript (mRNA), which is responsible for chronic myeloid leukemia (CML), and to the best of our knowledge it is the first time quantification of a specific mRNA directly in cancer cells is reported. This inexpensive and very easy to perform Au-nanoprobe based method allows quantification of unamplified total human RNA and specific detection of the oncogene transcript. The sensitivity settled by the Au-nanoprobes allows differential gene expression from $10 \mathrm{ng} / \mu \mathrm{l}$ of total RNA and takes less than 30 min to complete after total RNA extraction, minimizing RNA degradation. Also, at later stages, accumulation of malignant mutations may lead to resistance to chemotherapy and consequently poor outcome. Such a method, allowing for fast and direct detection and quantification of the chimeric $B C R-A B L \mathrm{mRNA}$, could speed up diagnostics and, if appropriate, revision of therapy. This assay may constitute a promising tool in early diagnosis of CML and could easily be extended to further target genes with proven involvement in cancer development.
\end{abstract}

\section{Background}

The National Cancer Institute envisions that over the next years, nanotechnology will result in significant advances in early detection, molecular imaging, targeted and multifunctional therapeutics, prevention and control of cancer [1]. Nanodiagnostics is a burgeoning field as more and improved techniques are becoming available for clinical diagnostics with increased sensitivity at lower costs [2-10]. Due to their optical properties, gold nanoparticles (AuNPs) have been used for DNA/RNA screening approaches, namely via functionalization with thiolated oligonucleotides (Au-nanoprobes), capable of specifically hybridizing with a complementary oligonucleotide sequence [9].

The surface plasmon resonance (SPR) of AuNPs is responsible for the intense colors - monodisperse $\mathrm{Au}$ nanoprobes $(\approx 13 \mathrm{~nm})$ appear red and exhibit a narrow SPR band centered around $520 \mathrm{~nm}$; a solution

\footnotetext{
* Correspondence: pmvb@fct.unl.pt

${ }^{1} \mathrm{CIGMH}$, Departamento de Ciências da Vida, Faculdade de Ciências e

Tecnologia, Universidade Nova de Lisboa, Campus de Caparica, 2829-516
} Caparica, Portugal

(c) 2010 Conde et al; licensee BioMed Central Ltd. This is an Open Access article distributed under the terms of the Creative Commons Attribution License (http://creativecommons.org/licenses/by/2.0), which permits unrestricted use, distribution, and reproduction in any medium, provided the original work is properly cited. containing aggregated Au-nanoprobes appears blue, due to a red shift of the SPR. Our method relies on visual and/or spectroscopy comparison of solutions before and after salt induced Au-nanoprobe aggregation -presence of complementary target prevents aggregation and the solution remains red (SPR peak at $\pm 520 \mathrm{~nm}$ ); non-complementary targets do not prevent Au-nanoprobe aggregation, resulting in a visible change of color from red to blue (red-shift of the SPR peak to 600-650 nm) [5-7]. The principle of gold nanoparticles assay method detection of RNA hybridization is depicted in Figure 1. This applied for detection of eukaryotic gene expression without reverse transcription or PCR amplification steps [6], and for Mycobacterium tuberculosis detection $[7,8]$.

Chronic myeloid leukemia (CML) is a clonal neoplastic disease of the hematopoietic stem cell, whose hallmark molecular event is the genetic $t(9 ; 22)$ (q34; $\mathrm{q} 11$ ) translocation known as the Philadelphia $(\mathrm{Ph})$ chromosome $[11,12]$. This translocation - $A B L$ gene (chromosome 9) and $B C R$ gene (chromosome 22) - originates a $B C R-A B L$ fusion gene, leading to the expression of a non-cross-linking method has already been successfully 


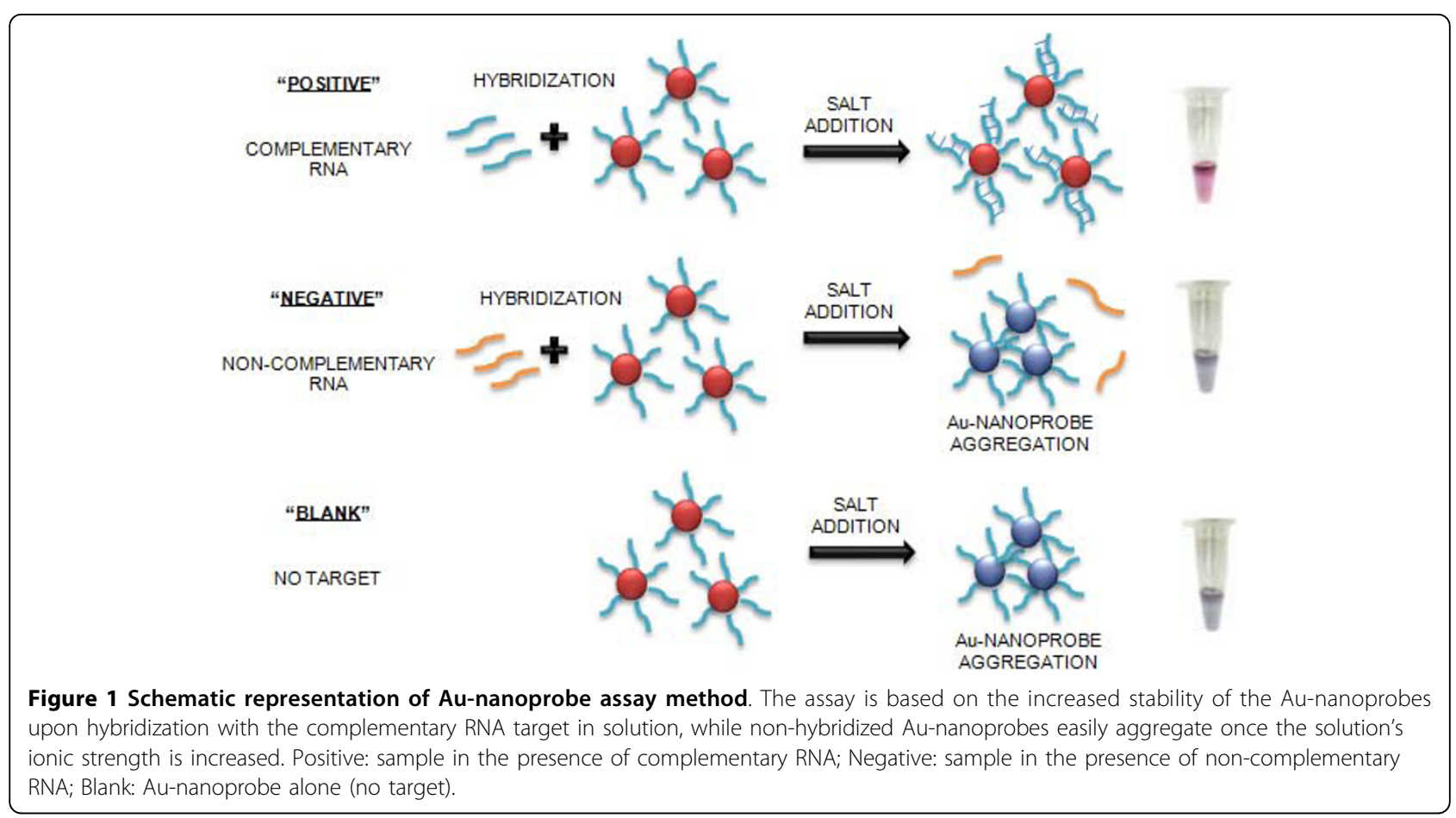

chimeric $\mathrm{BCR}-\mathrm{ABL}$ protein with tyrosine-kinase activity [13-15]. The most commonly used procedures for the initial diagnosis and management of CML patients are expensive and time consuming, e.g karyotype analysis, reverse transcriptase polymerase chain reaction analyses (RT-PCR) and fluorescence in-situ hybridization (FISH) [16-18]. Therefore, there is a need for molecular methods able to detect and quantify the $B C R-A B L$ fusion transcripts, which is of paramount relevance when monitoring minimal residual disease and genetic recurrence in patients known to harbor the translocation $[19,20]$.

Here we present an Au-nanoprobe based approach for the molecular recognition and quantification of $B C R$ $A B L \mathrm{~b} 3 \mathrm{a} 2$ (e14a2) fusion for the early diagnosis of CML, which is inexpensive very easy to perform and uses total human RNA as target without reverse transcription and/or amplification.

\section{Methods}

\section{Probe design and Au-nanoprobe synthesis}

The probe sequence 5'-thiol-CGCTGAAGGGCTTTTGAACT-3' and the complementary target derive from the $B C R-A B L$ b3a2 (e14a2) chimeric protein mRNA (Gene-Bank accession no. AJ 131466.1: 5'-TGGATTTAAGCAGAGTTCAAAAGCCCTTCAGCGGCCA GTA-3'), and the control oligonucleotide target sequences: $B C R$ (Gene-Bank accession no. NM 021574.2: 5'-TGGATTTAAGCAGAGTTCAAATCTGTACTGCACCCTGGAG-3'), ABL (Gene-Bank accession no. NM 005157.3: 5'-CTCCAGCTGTTATCTGGAAG AAGCCCTTCAGCGGCCAGTA-3') and an unrelated target (5'-AGGAAAACGATTCCTTCTAACAGAAATG TCCTGAGCAATC-3'). The way these sequences relate to each other is illustrated in Figure 2.

The $13 \mathrm{~nm}$ gold nanoparticles were prepared by the citrate reduction method described by Lee and Meisel [21]. The thiolated oligonucleotide was dissolved in $1 \mathrm{ml}$ of $0.1 \mathrm{M} \mathrm{DTT}$, extracted three times with ethyl acetate, and further purified through a desalting NAP-5 column (Pharmacia Biotech, Sweden) according to the manufacturer's instructions. The Au-nanoprobe was prepared as described in Baptista et al [5]. Briefly, $500 \mu \mathrm{l}$ of $10 \mu \mathrm{M}$ thiol modified oligonucleotide was initially incubated with $6 \mathrm{ml}$ of an aqueous solution of AuNPs $(\approx 8.55 \mathrm{nM})$ for at least $16 \mathrm{~h}$. After centrifugation $(20 \mathrm{~min}$ at 14500 G), the oily precipitate was washed with $5 \mathrm{ml}$ of $10 \mathrm{mM}$ phosphate buffer ( $\mathrm{pH} 8.0$ ), $0.1 \mathrm{M} \mathrm{NaCl}$, recentrifuged and redispersed in $5 \mathrm{ml}$ of the same buffer to a final concentration in AuNPs of $8.5 \mathrm{nM}$. The resulting Aunanoprobe was stored in the dark at $4^{\circ} \mathrm{C}$.

\section{Cell culture and total RNA isolation}

K562 erythroleukemic cells $(B C R-A B L$ positive cell line derived from CML patients in blast crisis) and HL-60 cell line, a human leukemic promyelocytic cell line (BCR-ABL negative) were cultured in 90\% RPMI 1640 and $10 \% \mathrm{FBS}$ at $37^{\circ} \mathrm{C}$ with $5 \% \mathrm{CO}_{2}$. Saccharomyces cerevisae cells were grown in YPD medium at $30^{\circ} \mathrm{C}$ 


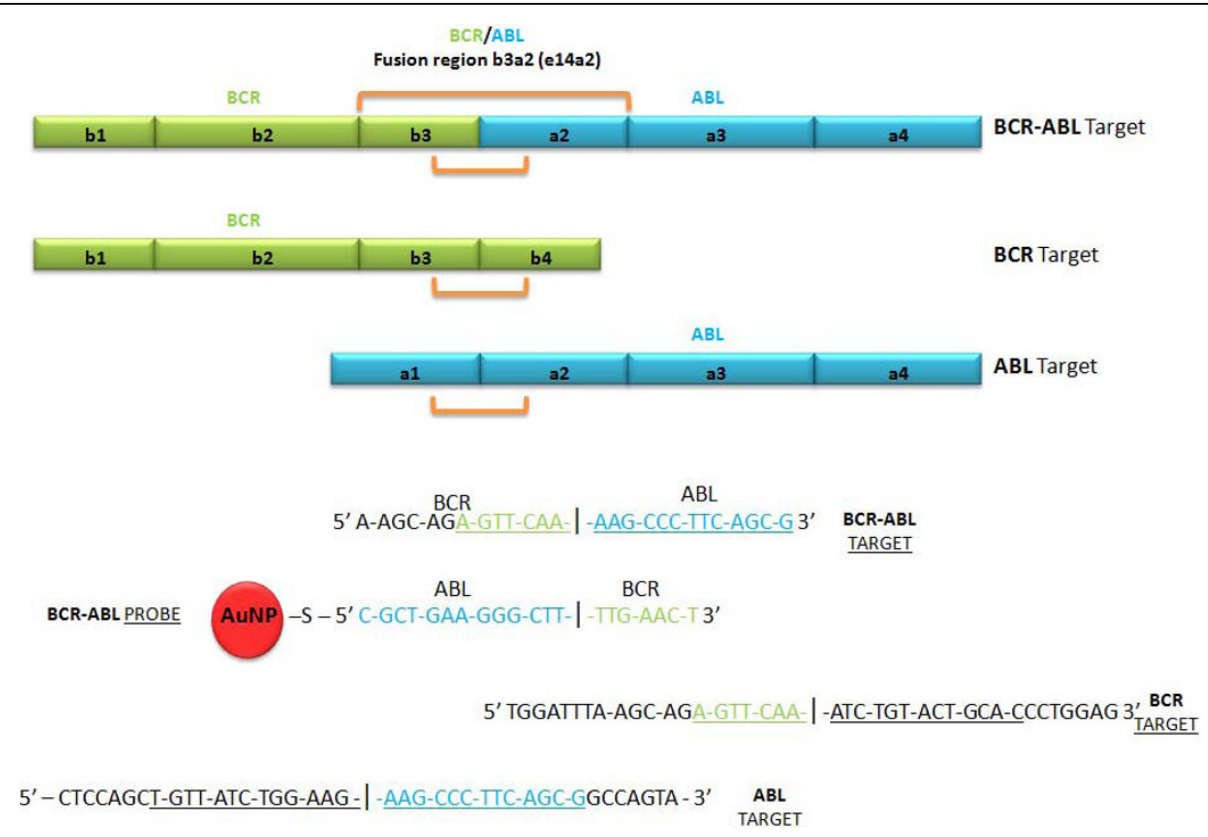

Figure 2 Oligonucleotide probe and target sequences designed for $B C R-A B L$ b3a2 (e14a2) junction and for $B C R$ and $A B L$ genes. Complementary and non-complementary target sequences were used to study the level of specific interaction between the target and the Aunanoprobes. $B C R-A B L$ fusion positive (100\% complementary); $B C R$ and $A B L$ gene sequences were used as controls (50\% non-complementary); and a completely unrelated sequence (100\% non-complementary) was used as negative control.

overnight. Human peripheral blood mononuclear cells (PBMC) from control individuals were separated from $3 \mathrm{ml}$ of heparinized peripheral venous blood by Ficoll gradient (Histopaque -1077 , Sigma-Aldrich, St. Louis, USA) according to manufacturer's specifications. Isolation of total RNA was performed using a High Pure RNA Isolation Kit (Roche Applied Science) according to the manufacturer's protocol. RNA concentration was determined by UV photometry and the RNA was stored at $-80^{\circ} \mathrm{C}$ until use. RNA integrity was evaluated on a $1 \%$ agarose gel stained by GelRed ${ }^{\mathrm{Tm}}$.

\section{Reverse transcription (RT) and PCR amplification}

Total RNA extracted from K562 cells was subjected to RT with Revert-AidTM M-MuLV Reverse Transcriptase (Fermentas, Vilnius, Lithuania) according to the manufacturer's specifications, using $20 \mu \mathrm{M}$ of BCR-ABLreverse primer, annealing at $42^{\circ} \mathrm{C}$ for $1 \mathrm{~h}$ and $70^{\circ} \mathrm{C}$ for 10 min to inactivate the reverse transcriptase. The reverse transcription reaction product, a 273-bp fragment of the human $B C R-A B L$ fusion gene (b3a2 junction), was PCR amplified using primers BCR-ABLforward (18 nt): 5'AGTCTCCGGGGCTCTATG-3' and BCR-ABLreverse (20 nt): 5'-GATTATAGCCTAAGACCCGG-3'. PCR amplification of the b3a2 region was carried out in $25 \mu \mathrm{l}$ using $0.25 \mu \mathrm{M}$ of primers, $0.2 \mathrm{mM}$ dNTPs with $1 \mathrm{U}$ Taq DNA polymerase (Amersham Biosciences, GE Healthcare, Europe, $\mathrm{GmbH})$. The PCR reactions were performed in duplicate on a MyCycler Thermocycler (Bio-rad). Thermal cycling conditions consisted of denaturation at $95^{\circ} \mathrm{C}$ for $5 \mathrm{~min}$ and 30 cycles of amplification, each cycle consisting of denaturation of $95^{\circ} \mathrm{C}$ for $30 \mathrm{~s}$, annealing at $52^{\circ} \mathrm{C}$ for $30 \mathrm{~s}$, elongation was at $72^{\circ} \mathrm{C}$ for $30 \mathrm{~s}$ and final elongation at $72^{\circ} \mathrm{C}$ for $5 \mathrm{~min}$ and cooling at $4^{\circ} \mathrm{C}$. The sequence of the PCR products was confirmed by sequencing.

\section{Real-Time RT-PCR assay}

The Real-Time PCR amplification was performed in a Corbett Research Rotor-Gene RG3000 using SYBR GreenER Real-Time PCR Kit (Invitrogen, Karlsbad, CA, USA) according to manufacturer's specifications in $50 \mu \mathrm{l}$ reactions containing cDNA from K562 and HL-60 celllines, $1 \times$ SYBR Green SuperMix and $200 \mathrm{nM}$ of BCRABLforward and BCR-ABLreverse. The amplification conditions consisted of $50^{\circ} \mathrm{C}$ for $2 \mathrm{~min}$ hold, $95^{\circ} \mathrm{C}$ during $10 \mathrm{~min}$ hold, followed by 40 cycles consisting of denaturation at $95^{\circ} \mathrm{C}$ for $30 \mathrm{~s}$, annealing at $52^{\circ} \mathrm{C}$ for $30 \mathrm{~s}$, extension at $72^{\circ} \mathrm{C}$ for $30 \mathrm{~s}$, with a final extension step at $72^{\circ} \mathrm{C}$ for $5 \mathrm{~min}$. All the results were originated from three independent experiments.

\section{Au-nanoprobe hybridization and color detection}

The Au-nanoprobe assay was performed in a total volume of $30 \mu \mathrm{l}$ containing the Au-nanoprobe at a final concentration of $2.5 \mathrm{nM}$, the appropriate targets 
at a final concentration of $100 \mathrm{fmol} / \mu \mathrm{l}(100 \%$ complementary $B C R-A B L$ target; $50 \%$ complementary $B C R$ and $A B L$ targets, and $100 \%$ non-complementary target) in $10 \mathrm{mM}$ phosphate buffer ( $\mathrm{pH} 8.0)$. Total RNA was used at a final concentration $10-60 \mathrm{ng} / \mu \mathrm{l}[100 \% \mathrm{com}$ plementary K562 cells RNA ( $B C R-A B L$ Positive); noncomplementary HL-60 cells RNA ( $B C R-A B L$ Negative)]. Blank measurements were made in exactly the same conditions but replacing target or total RNA for an equivalent volume of $10 \mathrm{mM}$ phosphate buffer (pH 8.0).

Following $5 \mathrm{~min}$ of denaturation at $95^{\circ} \mathrm{C}$, the mixtures were allowed to stand for $30 \mathrm{~min}$ at $25^{\circ} \mathrm{C}$ and $0.3 \mathrm{M}$ $\mathrm{MgCl}_{2}$ was added at a final concentration of $0.16 \mathrm{M}$. After $15 \mathrm{~min}$ at room temperature for color development, photographs were taken and assayed by UV-visible spectroscopic measurements of the SPR band. Absorption spectra were performed in a UNICAM, model UV2, UVvisible spectrophotometer with Ultra-Micro quartz cells (Hellma, Germany), using $10 \mathrm{mM}$ phosphate buffer ( $\mathrm{pH}$ 8.0), $0.1 \mathrm{M} \mathrm{NaCl}$ as reference. The areas under the curve $\left(\mathrm{AUC}_{500 \mathrm{~nm}-560 \mathrm{~nm}} / \mathrm{AUC}_{570 \mathrm{~nm}-630 \mathrm{~nm}}\right)$ were calculated with the values for absorbance for $500 \mathrm{~nm}-600 \mathrm{~nm} / 570$ $\mathrm{nm}-630 \mathrm{~nm}$ using the trapezoidal rule.

\section{Results and Discussion}

\section{Gold nanoprobe assay for target detection}

First, we used thiolated ssDNA, complementary to the fusion site of the $B C R-A B L$ mRNA, to functionalize gold nanoparticles and produce specific Au-nanoprobes. These nanoprobes were assessed in terms of specificity by means of total RNA mixtures spiked in with synthetic oligonucleotides harboring the fusion site $B C R-A B L$ b3a2. It should be noted that, in reality, patients may only harbor one copy of the fusion gene and the remaining copies of normal $A B L$ and $B C R$ should be still functional, thus expressing the normal mRNA sequence. Two oligonucleotides, each harboring the normal sequence of the $B C R$ and $A B L$ genes respectively, were used to evaluate the probe's capability to discriminate from similar sequences. Following salt addition, the presence of the respective complementary synthesized target, protected the Au-nanoprobes from aggregation and the solution remained red; whereas the presence of non-complementary targets does not protect from aggregation and the solution turned blue ( $B C R$ and $A B L$ controls only $50 \%$ complementary to the Au-nanoprobe) - Figure 3A. Absence of any target results in extensive aggregation (Blank). Only full hybridization of the Au-nanoprobe to a fully complementary synthetic sequence $(B C R-A B L$ fusion sequence) avoids aggregation, whereas semi-complementary targets (normal $A B L$ and $B C R$ gene sequence) do not show the same capability.
Based on the UV/Vis spectra (see Figure 4) obtained after inducing aggregation, Au-nanoprobe aggregation was evaluated in terms of SPR variation, i.e. a ratio between the free and aggregated fractions after $15 \mathrm{~min}$ incubation with $\left[\mathrm{MgCl}_{2}\right]=0.16 \mathrm{M}$. The ratio between the areas under the curve of the SPR was calculated using the trapezoidal rule $-\mathrm{AUC}_{500 \mathrm{~nm}-560 \mathrm{~nm}} / \mathrm{AUC}_{570}$ $\mathrm{nm}-630 \mathrm{~nm}$. A ratio of 1 may be considered as the point of equilibrium between non-aggregated and aggregated nanoprobe, hence the threshold to respectively consider the positive and negative discrimination of sequences (positive identification of complementary target ratio $>1$ ). Commonly, for discriminating between two significantly different aggregation levels, as for example in a YES/NO for identification of a given target, the ratio between the peaks at $520 \mathrm{~nm}$ and $600 \mathrm{~nm}$ is usually used. However, for identifying small differences in aggregation levels between two quantities for the same target, there is a need to decrease the noise level in the spectra. When establishing a ratio between two absorbance values, the error increases mainly due the noise in the spectra, which can be overcome (i.e. strongly reduced) by using an integral of the signal, i.e. the area under the curve.

The Au-nanoprobes were then used for the detection of the $B C R-A B L$ b3a2 fusion mRNA in total RNA extracted from K562 cells (BCR-ABL positive cell line), HL-60 cells ( $B C R-A B L$ negative cell line), human peripheral blood mononuclear cells (PBMC) and S. cerevisiae cells - Figure 3B. Total RNA from HL-60 cell line and PBMC only express the normal $B C R$ and $A B L$ transcripts, which are $50 \%$ complementary to the probe sequence. Total RNA from an unrelated organism (S. cerevisae) was used to confirm specificity of the detection method. The results originate from a minimum of three individual parallel hybridization experiments. $B C R-A B L$ fusion discrimination was observed only for samples containing the complementary RNA target (K562 cells). Samples containing the normal $B C R$ and $A B L$ genes showed a minor stabilization of the Au-nanoprobe, yet below the threshold for positive identification of the target (ratio $<1$ ).

\section{Gold nanoprobe assay for RNA quantification}

Once the specific identification of the target sequence was achieved, the Au-nanoprobes were used to evaluate both the limit of detection and quantification potential. For this purpose, different concentrations of the specific synthetic oligonucleotide target were used to spike in $20 \mathrm{ng} / \mu \mathrm{l}$ of total RNA extracted from the $B C R-A B L$ negative cell line HL-60. Our data indicate a linear correlation $\left(R^{2}=0.9966\right)$ between the $A C_{500}$ $\mathrm{nm}-560 \mathrm{~nm} / \mathrm{AUC}_{570 \mathrm{~nm}-630 \mathrm{~nm}}$ for target concentration range between 33 and $133 \mathrm{fmol} / \mu \mathrm{l}$ (Figure 5). A noncomplementary target was used in a parallel spike in 


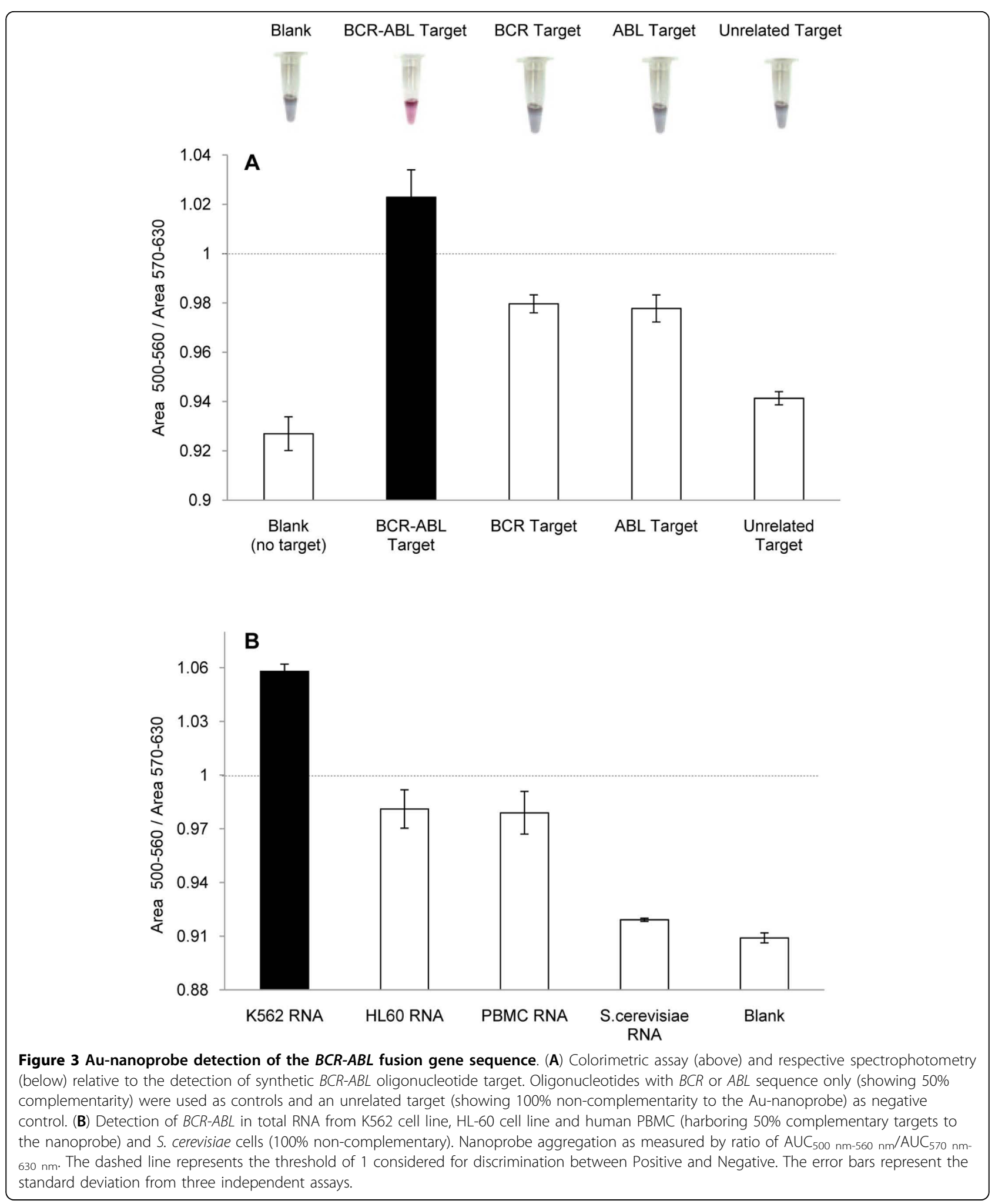



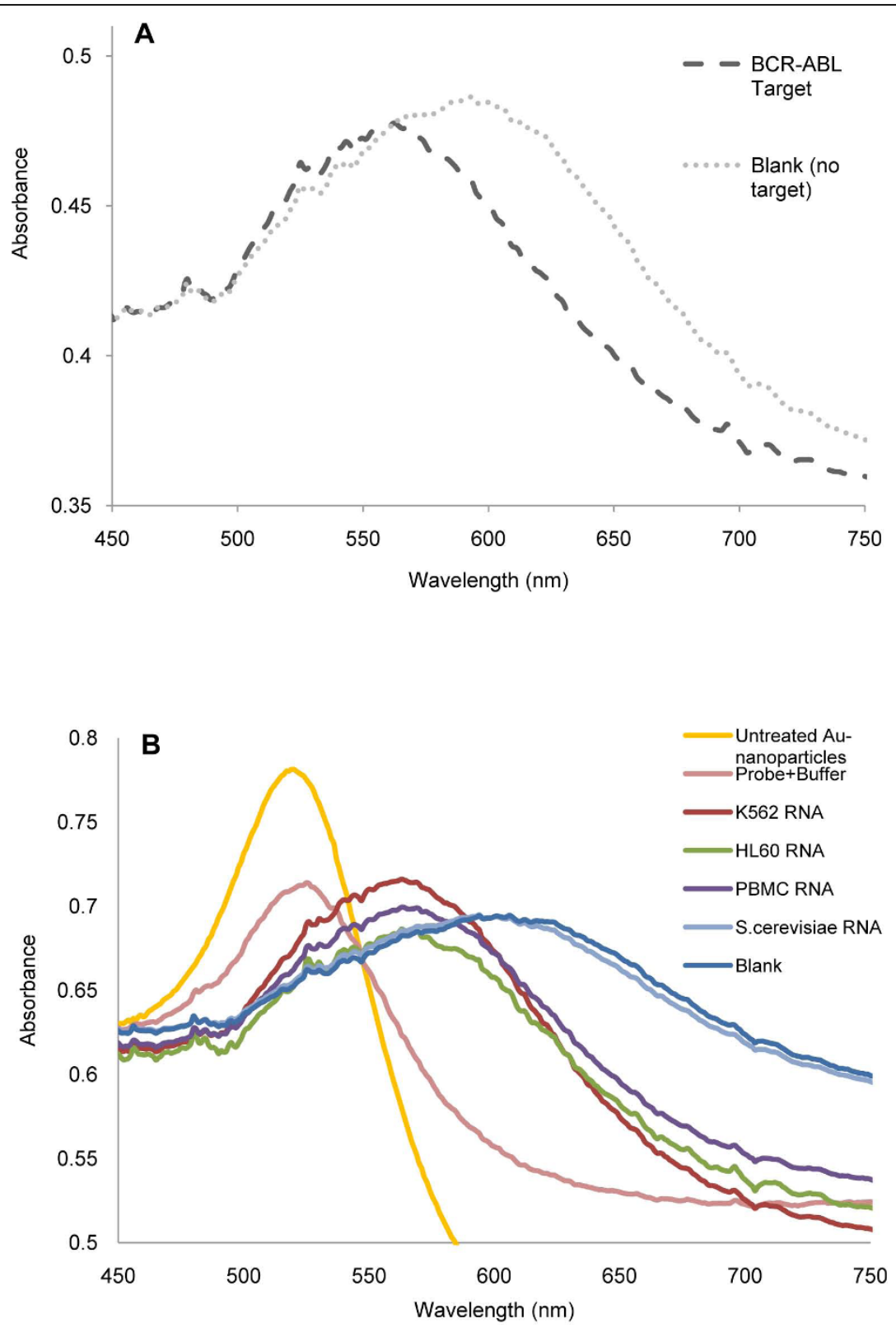

Figure 4 Au-nanoprobe UV/Vis spectra obtained after inducing aggregation. (A) UV/Vis spectra in absence (Blank) and in presence of target (BCR-ABL target). (B) UVNis spectra for the detection of the BCR-ABL b3a2 fusion mRNA in total RNA from K562 cells (BCR-ABL positive cell line), HL-60 cells (BCR-ABL negative cell line), human PBMC and S. cerevisiae cells; Au-nanoprobe alone before (Au-nanoprobe + buffer) and after (Blank) salt addition. All samples in $10 \mathrm{mM}$ phosphate buffer (pH 8.0). Also, spectral data from untreated Au-nanoparticles in sodium citrate.

experiment, where extensive aggregation of the $\mathrm{Au}$ nanoprobe was observed for all tested concentrations.

In order to validate the detection and quantification potential of the Au-nanoprobes in the positive cell line (K562), Real-time RT-PCR was used. Our method showed a linear correlation for $B C R-A B L$ detection within the range of 10-60 $\mathrm{ng} / \mu \mathrm{l}$ of total RNA (see Figure 6). A linear association $\left(R^{2}=0.9171\right)$ was found between the two methods, Real-Time RT-PCR and Au-nanoprobe, for $B C R-A B L$ detection (inset in Figure 6). Real-Time $\mathrm{RT}-\mathrm{PCR}$ is a more robust and sensitive technique but time consuming, more expensive and requiring expensive equipment and highly trained personnel.

\section{Conclusions}

In conclusion, we demonstrated the potential of an $\mathrm{Au}-$ nanoprobe based assay for the specific identification and quantification of aberrant expression of genes involved 


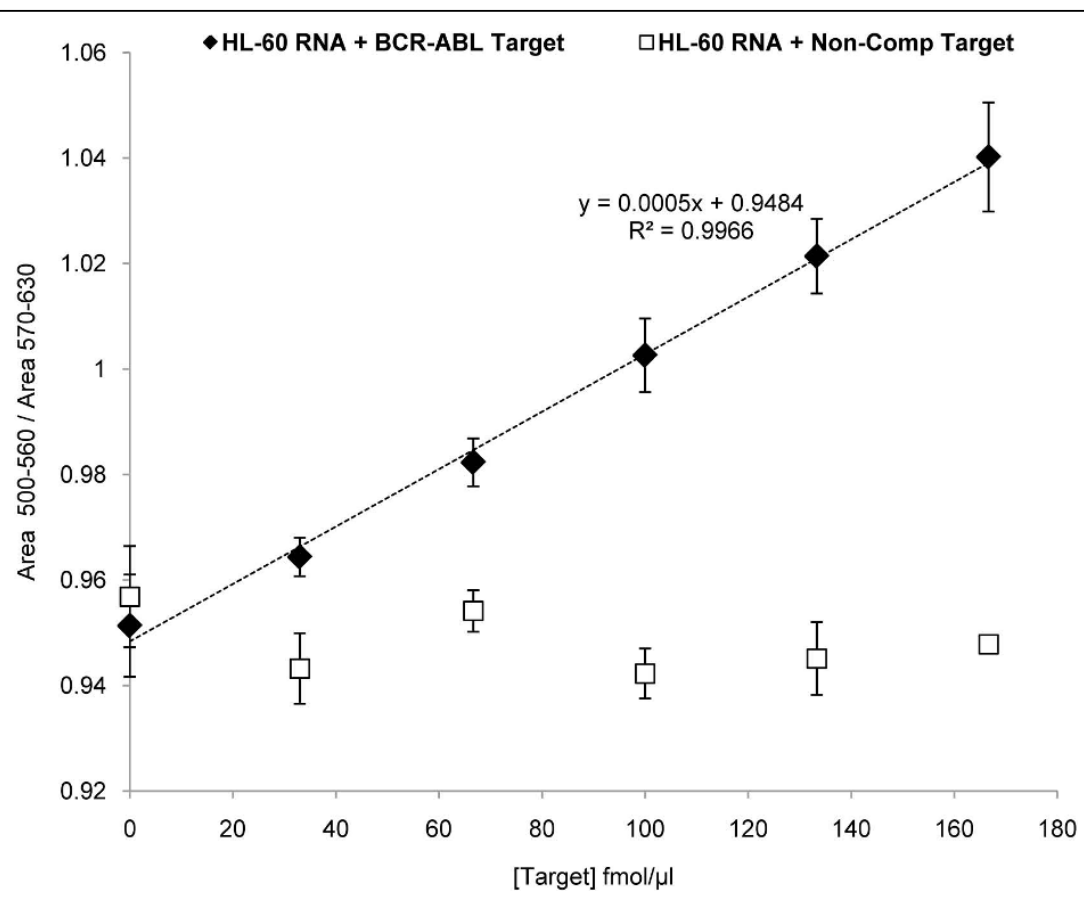

Figure 5 Quantification of $B C R-A B L$ by Au-nanoprobe. Ratio $A U C_{500} \mathrm{~nm}-560 \mathrm{~nm} / A \cup C_{570} \mathrm{~nm}-630 \mathrm{~nm}$ as function of specific target concentration in mixtures of $20 \mathrm{ng} / \mu \mathrm{l}$ total RNA from $B C R-A B L$ negative cell line HL-60 spiked in with increasing concentrations of the synthetic oligonucleotide (black diamond's - complementary target; blank squares - non-complementary target). The error bars represent the standard deviation from three independent assays.

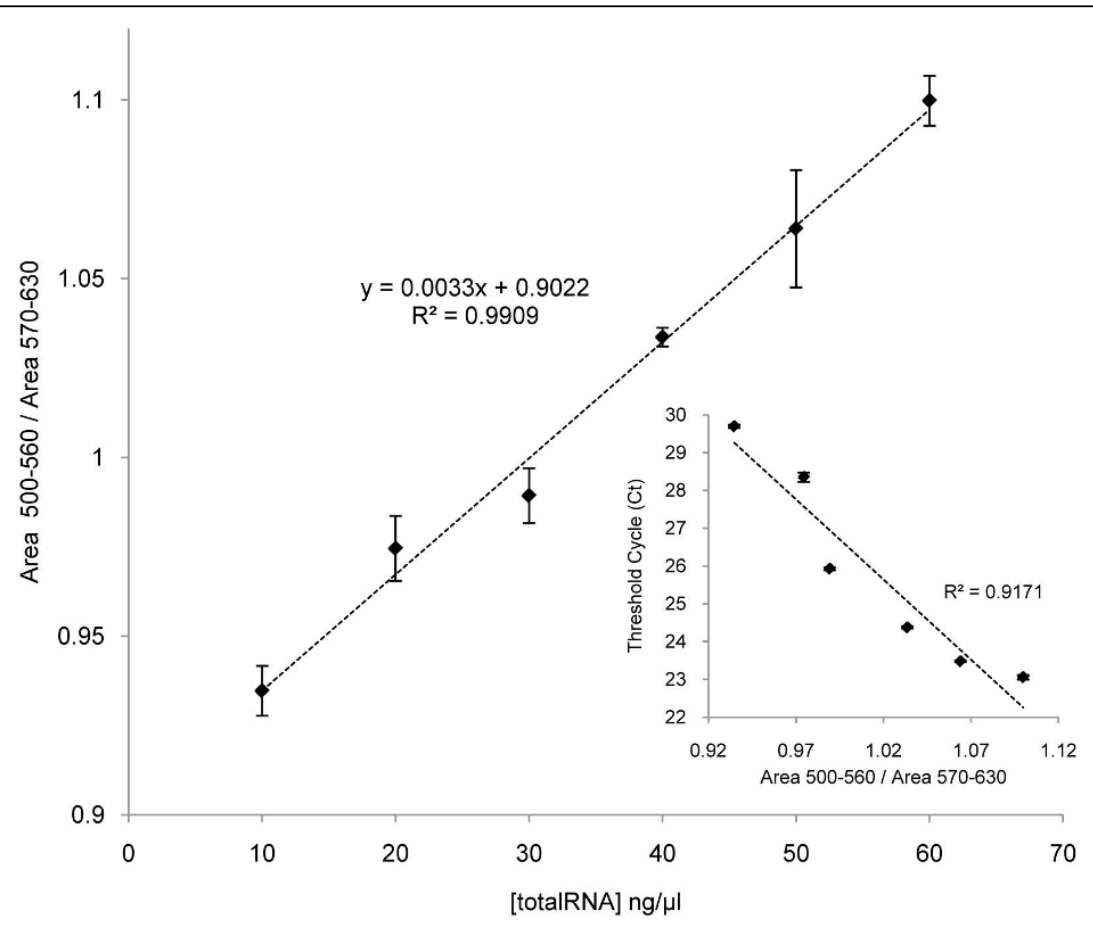

Figure 6 Au-nanoprobe based quantification of BRC-ABL fusion mRNA directly in total RNA extracted from K562 cell line. Nanoprobe

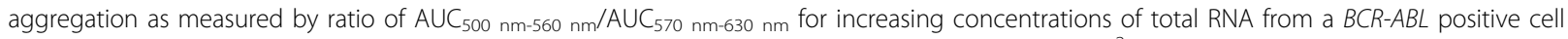
line (K562) - 10 to $60 \mathrm{ng} / \mathrm{\mu l}$. (Inset) Real-Time RT-PCR vs. Au-Nanoprobe Assays. A linear association $\left(R^{2}=0.9171\right.$ ) was found between the two methods. The error bars represent the standard deviation from three independent assays. 
in cancer development. This Au-nanoprobe strategy allowed for detection of less than $100 \mathrm{fmol} / \mu \mathrm{l}$ of a specific RNA target, with the possibility of discriminating between a positive and negative from as little as $10 \mathrm{ng} /$ $\mu \mathrm{l}$ of total RNA. As proof-of-concept we used the $B C R$ $A B L$ fusion product that is of paramount importance in chronic myeloid leukemia, showing the application potential in cancer diagnosis. To our knowledge, this is the first report on quantification of human mRNA directly from total RNA without reverse transcription or amplification. The assay has a total work-up time of less than 45 minutes with comparable sensitivity to those demonstrated by traditional molecular biology methodologies.

\section{List of Abbreviations}

(CML): Chronic myeloid leukemia; (AuNPs): Gold nanoparticles; (Aunanoprobes): Gold nanoprobes; (SPR): Surface plasmon resonance; (Ph) chromosome: Philadelphia; (PBMC): Peripheral blood mononuclear cells; (AUC): Area under the curve.

\section{Acknowledgements}

This work received the financial support of FCT/MCES through grants to CIGMH-FCT/UNL, PTDC/BIO/66514/2006 and PTDC/SAU-BEB/66511/2006. We thank Dr. A.S. Rodrigues for the human cell lines (K562 and HL-60) and M. Mateus for blood samples.

\section{Author details}

'CIGMH, Departamento de Ciências da Vida, Faculdade de Ciências e Tecnologia, Universidade Nova de Lisboa, Campus de Caparica, 2829-516 Caparica, Portugal. ${ }^{2}$ Instituto de Nanociencia de Aragón, Universidad de Zaragoza, Pedro Cerbuna 12, 50009, Zaragoza, Spain.

\section{Authors' contributions}

$\mathrm{JC}$ participated in the sequence alignment and design of the nanoprobe, carried out the nanoprobe synthesis, and performed the detection assays. JF participated in the design of the study. PB conceived the study, participated in its design and coordination, and drafted the manuscript. All authors read and approved the final manuscript.

\section{Competing interests}

The authors declare that they have no competing interests.

Received: 23 November 2009 Accepted: 24 February 2010 Published: 24 February 2010

\section{References}

1. National Cancer Institute: [http://nano.cancer.gov/].

2. Mirkin CA, Letsinger RL, Mucic RC, Storhoff JJ: A DNA-based method for rationally assembling nanoparticles into macroscopic materials. Nature 1996, 382(6592):607-609

3. Storhoff JJ, Lucas AD, Garimella V, Bao YP, Muller UR: Homogeneous detection of unamplified genomic DNA sequences based on colorimetric scatter of gold nanoparticle probes. Nat Biotechnol 2004, 22(7):883-887.

4. Thaxton CS, Georganopoulou DG, Mirkin CA: Gold nanoparticle probes for the detection of nucleic acid targets. Clin Chim Acta 2006, 363(12):120-126.

5. Baptista P, Pereira E, Eaton P, Doria G, Miranda A, Gomes I, Quaresma P, Franco R: Gold nanoparticles for the development of clinical diagnosis methods. Anal Bioanal Chem 2008, 391(3):943-950.

6. Baptista P, Doria G, Henriques D, Pereira E, Franco R: Colorimetric detection of eukaryotic gene expression with DNA-derivatized gold nanoparticles. J Biotechnol 2005, 119(2):111-117.
7. Baptista PV, Koziol-Montewka M, Paluch-Oles J, Doria G, Franco R: Goldnanoparticle-probe-based assay for rapid and direct detection of Mycobacterium tuberculosis DNA in clinical samples. Clin Chem 2006, 52(7):1433-1434.

8. Costa P, Amaro A, Botelho A, Inácio J, Baptista PV: Gold nanoprobes assay for identification of mycobacteria from the Mycobacterium tuberculosis complex. Clin Microbiol Infect 2009.

9. Doria G, Franco R, Baptista P: Nanodiagnostics: fast colorimetric method for single nucleotide polymorphism/mutation detection. IET Nanobiotechnol 2007, 1(4):53-57.

10. Griffin J, Singh AK, Senapati D, Lee E, Gaylor K, Jones-Boone J, Ray PC: Sequence-specific HCV RNA quantification using the size-dependent nonlinear optical properties of gold nanoparticles. Small 2009, 5(7):839-845.

11. Hehlmann R, Hochhaus A, Baccarani M: Chronic myeloid leukaemia. Lancet 2007, 370(9584):342-350,

12. Shet $A S$, Jahagirdar BN, Verfaillie CM: Chronic myelogenous leukemia: mechanisms underlying disease progression. Leukemia 2002, 16(8):1402-1411.

13. Ren R: Mechanisms of $B C R-A B L$ in the pathogenesis of chronic myelogenous leukaemia. Nat Rev Cancer 2005, 5(3):172-183.

14. Wong S, Witte ON: The BCR-ABL story: bench to bedside and back. Annu Rev Immunol 2004, 22:247-306.

15. Melo J: Inviting leukemic cells to waltz with the devil. Nat Med 2001, 7(2):156-157.

16. Ou J, Vergilio JA, Bagg A: Molecular diagnosis and monitoring in the clinical management of patients with chronic myelogenous leukemia treated with tyrosine kinase inhibitors. Am J Hematol 2008, 83(4):296-302.

17. Apperley JF: Part I: mechanisms of resistance to imatinib in chronic myeloid leukaemia. Lancet Oncol 2007, 8(11):1018-1029.

18. Burmeister T, Maurer J, Aivado M, Elmaagacli AH, Grunebach F, Held KR, Hess G, Hochhaus A, Hoppner W, Lentes KU, Lubbert M, Schafer KL, Schafhausen P, Schmidt CA, Schuler F, Seeger K, Seelig R, Thiede C, Viehmann S, Weber C, Wilhelm S, Christmann A, Clement JH, Ebener U, Enczmann J, Leo R, Schleuning M, Schoch R, Thiel E: Quality assurance in RT-PCR-based BCR/ABL diagnostics-results of an interlaboratory test and a standardization approach. Leukemia 2000, 14(10):1850-1856.

19. Beillard E, Pallisgaard N, van dW, Bi W, Dee R, van der SE, Delabesse E, Macintyre E, Gottardi E, Saglio G, Watzinger F, Lion T, van Dongen JJ, Hokland P, Gabert J: Evaluation of candidate control genes for diagnosis and residual disease detection in leukemic patients using 'real-time' quantitative reverse-transcriptase polymerase chain reaction (RQ-PCR) a Europe against cancer program. Leukemia 2003, 17(12):2474-2486.

20. Gabert J, Beillard E, van dW, Bi W, Grimwade D, Pallisgaard N, Barbany G, Cazzaniga G, Cayuela JM, Cave H, Pane F, Aerts JL, De MD, Thirion X, Pradel V, Gonzalez M, Viehmann S, Malec M, Saglio G, van Dongen JJ: Standardization and quality control studies of 'real-time' quantitative reverse transcriptase polymerase chain reaction of fusion gene transcripts for residual disease detection in leukemia - a Europe Against Cancer program. Leukemia 2003, 17(12):2318-2357.

21. Lee PC, Meisel D: Adsorption and surface-enhanced Raman of dyes on silver and gold sols. J Phys Chem 1982, 86(17):3391-3395.

doi:10.1186/1477-3155-8-5

Cite this article as: Conde et al:: RNA quantification using gold nanoprobes - application to cancer diagnostics. Journal of Nanobiotechnology 2010 8:5. 